\title{
Front Matter: Volume 7568
}

, "Front Matter: Volume 7568," Proc. SPIE 7568, Imaging, Manipulation, and Analysis of Biomolecules, Cells, and Tissues VIII, 756801 (29 March 2010); doi: $10.1117 / 12.858683$

SPIE. Event: SPIE BiOS, 2010, San Francisco, California, United States 
PROGRESS IN BIOMEDICAL OPTICS AND IMAGING

Vol. 11, No. 21

\title{
Imaging, Manipulation, and Analysis of Biomolecules, Cells, and Tissues VIII
}

\author{
Daniel L. Farkas \\ Dan V. Nicolau \\ Robert C. Leif \\ Editors
}

23-25 January 2010

San Francisco, California, United States

Sponsored and Published by

SPIE

Volume 7568

Proceedings of SPIE, 1605-7422, v. 7568

SPIE is an international society advancing an interdisciplinary approach to the science and application of light. 
The papers included in this volume were part of the technical conference cited on the cover and title page. Papers were selected and subject to review by the editors and conference program committee. Some conference presentations may not be available for publication. The papers published in these proceedings reflect the work and thoughts of the authors and are published herein as submitted. The publisher is not responsible for the validity of the information or for any outcomes resulting from reliance thereon.

Please use the following format to cite material from this book:

Author(s), "Title of Paper," in Imaging, Manipulation, and Analysis of Biomolecules, Cells, and Tissues VIII, edited by Daniel L. Farkas, Dan V. Nicolau, Robert C. Leif, Proceedings of SPIE Vol. 7568 (SPIE, Bellingham, WA, 2010) Article CID Number.

ISSN 1605-7422

ISBN 9780819479648

Published by

SPIE

P.O. Box 10, Bellingham, Washington 98227-0010 USA

Telephone +1 3606763290 (Pacific Time) · Fax +1 3606471445

SPIE.org

Copyright (C) 2010, Society of Photo-Optical Instrumentation Engineers.

Copying of material in this book for internal or personal use, or for the internal or personal use of specific clients, beyond the fair use provisions granted by the U.S. Copyright Law is authorized by SPIE subject to payment of copying fees. The Transactional Reporting Service base fee for this volume is $\$ 18.00$ per article (or portion thereof), which should be paid directly to the Copyright Clearance Center (CCC), 222 Rosewood Drive, Danvers, MA 01923. Payment may also be made electronically through CCC Online at copyright.com. Other copying for republication, resale, advertising or promotion, or any form of systematic or multiple reproduction of any material in this book is prohibited except with permission in writing from the publisher. The CCC fee code is 1605 $7422 / 10 / \$ 18.00$.

Printed in the United States of America.

Publication of record for individual papers is online in the SPIE Digital Library.

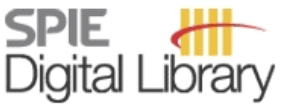

SPIEDigitallibrary.org

Paper Numbering: Proceedings of SPIE follow an e-First publication model, with papers published first online and then in print and on CD-ROM. Papers are published as they are submitted and meet publication criteria. A unique, consistent, permanent citation identifier (CID) number is assigned to each article at the time of the first publication. Utilization of CIDs allows articles to be fully citable as soon they are published online, and connects the same identifier to all online, print, and electronic versions of the publication. SPIE uses a six-digit CID article numbering system in which:

- The first four digits correspond to the SPIE volume number.

- The last two digits indicate publication order within the volume using a Base 36 numbering system employing both numerals and letters. These two-number sets start with 00, 01, 02, 03, 04, $05,06,07,08,09,0 A, 0 B \ldots$. OZ, followed by 10-1Z, 20-2Z, etc.

The CID number appears on each page of the manuscript. The complete citation is used on the first page, and an abbreviated version on subsequent pages. Numbers in the index correspond to the last two digits of the six-digit CID number. 


\section{Contents}

ix Conference Committee

\section{SESSION 1 CELL IMAGING}

756803 Total internal reflection holographic microscopy for quantitative phase characterization of cellular adhesion [7568-58]

W. M. Ash III, D. Clark, C.-M. Lo, M. K. Kim, Univ. of South Florida (United States)

756804 The fluorescence lifetime of BRI1-GFP as probe for the noninvasive determination of the membrane potential in living cells [7568-38]

K. Elgass, K. Casear, F. Schleifenbaum, A. J. Meixner, K. Harter, Eberhard Karls Univ. Tübingen (Germany)

756806 Two-photon microscopy of living cells by simultaneously exciting multiple endogenous fluorophores and fluorescent proteins [7568-33]

W. Zheng, D. Li, J. Y. Qu, Hong Kong Univ. of Science and Technology (Hong Kong, China)

756808 Dynamic phase imaging of host cells attacked by Vibrio vulnificus using quantitative phase microscopy [7568-79]

S. Lee, W. Yang, J. Y. Lee, Gwangju Institute of Science and Technology (Korea, Republic of); M. H. Cha, Y. R. Kim, Dongshin Univ. (Korea, Republic of); D. Y. Kim, Gwangju Institute of Science and Technology (Korea, Republic of)

$7568 \mathrm{OA}$ Gold nanorods for cell imaging with confocal reflectance microscopy and two-photon fluorescence microscopy [7568-04]

J.-Y. Chen, P.-N. Wang, Fudan Univ. (China)

\section{SESSION 2 TISSUE IMAGING}

7568 OB Do you have an innovative idea that can revolutionize cancer research? Opportunities and resources for innovative cancer technologies from the National Cancer Institute (Invited Paper) [7568-03]

M. D. Lim, C. C. Compton, National Institutes of Health (United States)

7568 OD A comparative study of different instrumental concepts for spectrally and lifetime-resolved multiphoton intravital tomography (5D-IVT) in dermatological applications [7568-15]

M. Schwarz, I. Riemann, F. Stracke, Fraunhofer-Institut für Biomedizinische Technik (Germany); V. Huck, Univ. Münster (Germany); C. Gorzelanny, S. W. Schneider, Univ. Heidelberg (Germany); K. König, JenLab GmbH (Germany); S. Puschmann, V. Lutz,

N. Sommer, C. Rahn, S. Gallinat, H. Wenck, K.-P. Wittern, F. Fischer, Beiersdorf AG (Germany)

7568 OF Selective excitation light fluorescence (SELF) imaging [7568-88]

M. Khojasteh, British Columbia Cancer Research Ctr. (Canada) and Univ. of British Columbia

(Canada); C. MacAulay, British Columbia Cancer Research Ctr. (Canada) 
7568 OG Plant abiotic stress diagnostic by laser induced chlorophyll fluorescence spectral analysis of in vivo leaf tissue of biofuel species [7568-06]

A. S. Gouveia-Neto, E. A. Silva, Jr., E. B. Costa, L. A. Bueno, L. M. H. Silva, M. M. C. Granja, M. J. L. Medeiros, T. J. R. Câmara, L. G. Willadino, Univ. Federal Rural de Pernambuco (Brazil)

$7568 \mathrm{OH} \quad$ Specific binding of molecularly targeted agents to pancreas tumors and impact on observed optical contrast [7568-74]

K. S. Samkoe, S. K. Hextrum, O. Pardesi, J. A. O'Hara, Dartmouth College (United States);

T. Hasan, Wellman Ctr. for Photomedicine, Massachusetts General Hospital (United States);

B. W. Pogue, Dartmouth College (United States)

7568 Ol Spectral ophthalmoscopy based on supercontinuum [7568-75]

Y.-H. Cheng, J.-Y. Yu, H.-H. Wu, B.-J. Huang, S.-W. Chu, National Taiwan Univ. (Taiwan)

$75680 \mathrm{~J} \quad$ Estrogen receptor-targeted optical imaging of breast cancer cells with near-infrared fluorescent dye [7568-83]

I. Jose, Birla Institute of Technology and Sciences, Goa (India); K. Deodhar, Indian Institute of Technology Bombay (India); S. V. Chiplunkar, M. Patkar, Advanced Ctr. for Treatment, Research \& Education in Cancer Research Institute (India)

7568 OK Confocal microscopy for automatic measurement of the density and distance between elastin fibers of histologic preparations of normotensive and hypertensive patients [7568-57] G. Vieira, D. P. Ferro, R. L. Adam, A. A. de Thomaz, C. L. Cesar, K. Metze, Univ. Estadual de Campinas (Brazil)

$75680 \mathrm{M} \quad$ Modulated Raman spectroscopy technique for real-time fluorescence rejection [7568-39] M. Mazilu, A. C. De Luca, A. Riches, S. Herrington, K. Dholakia, Univ. of St. Andrews (United Kingdom)

\section{SESSION 3 MICRO: IMAGING, MANIPULATION, PROBING}

$75680 \mathrm{~N} \quad$ High-throughput microfluidics and ultrafast optics for in vivo compound/genetic discoveries (Invited Paper) [7568-42]

C. B. Rohde, C. Gilleland, C. Samara, M. F. Yanik, Massachusetts Institute of Technology (United States)

7568 OP High-throughput magnetic flow sorting of human cells selected on the basis of magnetophoretic mobility [7568-73]

L. M. Reece, L. Sanders, Purdue Univ. (United States); D. Kennedy, Purdue Univ. (United States) and IKOTECH, LLC (United States); B. Guernsey, IKOTECH, LLC (United States); P. Todd, Techshot, Inc. (United States); J. F. Leary, Purdue Univ. (United States)

$75680 Q \quad$ Mechanical anisotropy and adaptation of metastatic cells probed by magnetic microbeads [7568-50]

Z. Zhang, Y. Shi, S. M. Jhiang, C.-H. Menq, The Ohio State Univ. (United States)

7568 OR Laser electrospray mass spectrometry of adsorbed molecules at atmospheric pressure [7568-52]

J. J. Brady, E. J. Judge, K. Simon, R. J. Levis, Temple Univ. (United States) 
7568 OU MICAO: first universal all-in-the-box adaptive optics plug in accessory for standard high resolution microscopy [7568-90]

J. Andilla, X. Levecq, Imagine Optic SA (France)

7568 OV Temporal and spatial in vivo optical analysis of microtubules in Neurospora crassa [7568-29] M. Held, C. Edwards, D. V. Nicolau, Univ. of Liverpool (United Kingdom)

7568 0X Confocal fluorescence detection for 3D cultured mammalian cells in a microfluidic cell culture system [7568-41]

J. Choi, Yonsei Univ. (Korea, Republic of); J. H. Sung, M. L. Shuler, Cornell Univ. (United States);

D. Kim, Yonsei Univ. (Korea, Republic of)

\section{SESSION 4 BIOMOLECULAR IMAGING}

7568 OY High-throughput vibrational cytometry based on nonlinear Raman microspectroscopy (Invited Paper) [7568-51]

R. Arora, G. I. Petrov, V. V. Yakovlev, Univ. of Wisconsin-Milwaukee (United States)

$75680 Z$ Label-free quantitative detection of biomarkers [7568-70]

D. P. Davé, S. Chirvi, The Univ. of Texas at Arlington (United States)

756810 Ultrasensitive label-free detection and quantitation of DNA hybridization via terahertz spectrometry [7568-08]

A. Rahman, Applied Research and Photonics Inc. (United States); B. Stanley, The Pennsylvania State Univ. College of Medicine (United States); A. K. Rahman, Applied Research and Photonics Inc. (United States)

756811 The use of time-resolved fluorescence in gel-based proteomics for improved biomarker discovery [7568-61]

A. Sandberg, Karolinska Institutet (Sweden); V. Buschmann, P. Kapusta, R. Erdmann,

PicoQuant GmbH (Germany); Å. M. Wheelock, Karolinska Institutet (Sweden)

756812 Spectroscopic phase microscopy for quantifying hemoglobin concentrations in intact red blood cells [7568-66]

Y. Park, Massachusetts Institute of Technology (United States); T. Yamauchi, Massachusetts Institute of Technology (United States) and Hamamatsu Photonics K. K. (Japan); W. Choi, Massachusetts Institute of Technology (United States) and Korea Univ. (Korea, Republic of); R. Dasari, M. S. Feld, Massachusetts Institute of Technology (United States)

756815 Intravital real-time study of tissue response to controlled laser-induced cavitation using 500-ps UV laser pulses focused in murine gut mucosa under online dosimetry and spectrally resolved 2-photon microscopy [7568-82]

R. Orzekowsky-Schroeder, A. Klinger, A. Schüth, S. Freidank, G. Hüttmann, A. Gebert, A. Vogel, Univ. zu Lübeck (Germany)

756816 High-speed confocal fluorescence lifetime imaging microscopy by analog mean-delay method [7568-10]

Y. Won, D. Kim, W. Yang, D. Y. Kim, Gwangju Institute of Science and Technology (Korea, Republic of) 
756817 Denoising of single scan Raman spectroscopy signals [7568-67]

L. Quintero, Univ. de Puerto Rico Mayagüez (United States); C. Matthäus, Northeastern Univ. (United States); S. Hunt, Univ. de Puerto Rico Mayagüez (United States); M. Diem,

Northeastern Univ. (United States)

\section{SESSION 5 CYTOMICS}

756818 Practical way to develop 10-color flow cytometry protocols for the clinical laboratory (Invited Paper) [7568-17]

A. Tárnok, J. Bocsi, Univ. Leipzig (Germany)

756819 Time-gated real-time bioimaging system using multicolor microsecond-lifetime silica nanoparticles (Invited Paper) [7568-36]

D. Jin, J. Piper, Macquarie Univ. (Australia); J. Yuan, Dalian Univ. of Technology (China);

R. Leif, Newport Instruments (United States)

$75681 \mathrm{~A} \quad$ An analog method to produce time-gated images [7568-91]

R. C. Leif, Newport Instruments (United States); S. Yang, Newport Instruments (United States) and Phoenix Flow Systems (United States)

7568 1B Label-free single cell analysis with a chip-based impedance flow cytometer [7568-16] A. Pierzchalski, Univ. Leipzig (Germany); M. Hebeisen, Leister Process Technologies (Switzerland); A. Mittag, Univ. Leipzig (Germany); M. Di Berardino, Leister Process Technologies (Switzerland); A. Tarnok, Univ. Leipzig (Germany)

7568 1D Cyto•IQ: an adaptive cytometer for extracting the noisy dynamics of molecular interactions in live cells [7568-55]

D. A. Ball, Virginia Polytechnic Institute and State Univ. (United States); S. E. Moody, Orca Photonic Systems, Inc. (United States); J. Peccoud, Virginia Polytechnic Institute and State Univ. (United States)

$75681 \mathrm{E} \quad$ Image processing techniques in computer-assisted patch clamping [7568-13]

M. Azizian, R. Patel, Univ. of Western Ontario (Canada) and Canadian Surgical Technologies and Advanced Robotics (Canada); C. Gavrilovici, M. O. Poulter, Univ. of Western Ontario (Canada) and Robarts Research Institute (Canada)

7568 1F Image classifiers for the cell transformation assay: a progress report [7568-20] C. Urani, G. F. Crosta, C. Procaccianti, P. Melchioretto, Univ. degli Studi di Milano-Bicocca (Italy); F. M. Stefanini, Univ. degli Studi di Firenze (Italy)

$75681 \mathrm{G}$ Automatic image analysis method for quantification of tube formation by endothelial cells in vitro [7568-27]

D. Chen, SAIC-Frederick, Inc., National Cancer Institute (United States); R. Motiejunaite, Harvard Medical School (United States) and Vilnius Univ. (Lithuania); A. Kazlauskas, Harvard Medical School (United States); P. Gudla, J. Collins, S. Lockett, SAIC-Frederick, Inc., National Cancer Institute (United States)

$756811 \quad$ Impulsive noise reduction in Raman spectroscopy images [7568-69]

L. Quintero, Univ. de Puerto Rico Mayagüez (United States); M. Miljković, Northeastern Univ. (United States); S. Hunt, Univ. de Puerto Rico Mayagüez (United States); C. Matthäus, M. Diem, Northeastern Univ. (United States) 
7568 i Cellular spectroscopy and multi-angle light scattering by flow cytometry: optical test bench as a developmental tool (Invited Paper) [7568-92]

G. Wiegand, I. Avital, National Institutes of Health (United States)

\section{SESSION 6 NEW IMAGING TECHNIQUES}

7568 IK Angular domain spectroscopic imaging of turbid media using silicon micromachined microchannel arrays [7568-34]

F. Vasefi, Simon Fraser Univ. (Canada) and Lawson Health Research Institute (Canada);

E. Ng, Lawson Health Research Institute (Canada) and Univ. of Western Ontario (Canada);

M. Najiminaini, Simon Fraser Univ. (Canada) and Lawson Health Research Institute

(Canada); G. Albert, Lawson Health Research Institute (Canada); B. Kaminska,

G. H. Chapman, Simon Fraser Univ. (Canada); J. J. L. Carson, Lawson Health Research Institute (Canada) and Univ. of Western Ontario (Canada)

$75681 \mathrm{~L} \quad$ Real-time megapixel multispectral bioimaging [7568-60]

J. M. Eichenholz, Ocean Optics, Inc. (United States) and Ocean Thin Films Inc. (United States); N. Barnett, Y. Juang, Ocean Optics, Inc. (United States); D. Fish, Ocean Thin Films Inc. (United States); S. Spano, Finger Lakes Engineering (United States); E. Lindsley, D. L. Farkas,

Cedars-Sinai Medical Ctr. (United States)

$7568 \mathrm{iN}$ Fluorescence intensity decay shape analysis microscopy (FIDSAM) for quantitative and sensitive live-cell imaging [7568-12]

S. Peter, K. Elgass, M. Sackrow, K. Caesar, Eberhard Karls Univ. Tübingen (Germany);

A.-K. Born, K. Maniura, Swiss Federal Labs. for Materials Testing and Research (Switzerland);

K. Harter, A. J. Meixner, F. Schleifenbaum, Eberhard Karls Univ. Tübingen (Germany)

756810 Speckle-field digital holographic microscopy [7568-65]

Y. Park, Massachusetts Institute of Technology (United States); W. Choi, Massachusetts Institute of Technology (United States) and Korea Univ. (Korea, Republic of); Z. Yaqoob, R. Dasari, Massachusetts Institute of Technology (United States); K. Badizadegan, Massachusetts Institute of Technology (United States), Harvard Medical School (United States), and Massachusetts General Hospital (United States); M. S. Feld, Massachusetts Institute of Technology (United States)

7568 IP Multicolor digital holographic microscope (DHM) for biological purposes [7568-47] Z. Göröcs, M. Kiss, V. Tóth, L. Orzó, S. Tőkés, Computer and Automation Research Institute (Hungary)

$75681 Q \quad$ Polarization control and tomography for nonlinear microscopy [7568-54]

D. Kupka, O. Masihzadeh, P. Schlup, R. A. Bartels, Colorado State Univ. (United States)

POSTER SESSION

7568 iT Topography, nanomechanics, and cell surface components of cancer cells examined by combined atomic force microscopy and Raman microspectroscopy [7568-81]

Y. Wu, G. D. McEwen, S. M. Baker, T. Yu, T. A. Gilbertson, D. B. DeWald, A. Zhou, Utah State Univ. (United States) 
7568 IV Cerebral blood flow imaging using time-series analysis of indocyanine green molecular dynamics in mice [7568-53]

T. Ku, J. Lee, C. Choi, Korea Advanced Institute of Science and Technology (Korea,

Republic of)

7568 1X Optical modulation of smooth muscle cell contraction [7568-45]

J. Yoon, M. Choi, C. Choi, Korea Advanced Institute of Science and Technology (Korea, Republic of)

7568 IY Autophagy induction upon reactive oxygen species in Cd-stressed Arabidopsis thaliana [7568-30]

W. Zhang, W. Chen, South China Normal Univ. (China)

756812 The preliminary study of autophagy induction of SA and MeSA by confocal [7568-31]

L. Yun, W. Chen, South China Normal Univ. (China)

756820 Combined optical coherence tomography based on the extended Huygens-Fresnel principle and histology of mouse skin [7568-32]

S. Wu, Z. Li, H. Li, Fujian Normal Univ. (China); X. Shi, Photop Technologies of Fuzhou (China)

756821 Development of in vivo confocal microscope for reflection and fluorescence imaging simultaneously [7568-25]

M. Ahn, B. Chun, C. Song, D. Gweon, Korea Advanced Institute of Science and Technology (Korea, Republic of)

756822 Effects of $\mathrm{NaCl}$ on photosynthesis in Arabidopsis and Thellungiella leaves based on the fluorescence spectra, the fast chlorophyll fluorescence induction dynamics analysis, and the delayed fluorescence technique [7568-26]

Z. Chen, W. Chen, South China Normal Univ. (China)

756823 Evaluation of human serum of severe rheumatoid arthritis by confocal Raman spectroscopy [7568-14]

C. S. Carvalho, L. Raniero, A. M. E. Santo, Univ. do Vale do Paraíba (Brazil); M. M. Pinheiro, L. E. C. Andrade, Univ. Federal de São Paulo (Brazil); M. A. G. Cardoso, Univ. do Vale do Paraíba (Brazil); J. S. Junior, BIOMED (Brazil); A. A. Martin, Univ. do Vale do Paraíba (Brazil)

756824 Tomographic imaging system using digital holographic technique based on integrating four buckets phase shifting interferometry [7568-40]

G. Min, J. W. Kim, W. J. Choi, Gwangju Institute of Science of Technology (Korea, Republic of); E. S. Choi, Chosun Univ. (Korea, Republic of); B. H. Lee, Gwangju Institute of Science of Technology (Korea, Republic of)

756825 Immersion Mirau interferometry for label-free live cell imaging in an epi-illumination geometry [7568-93]

O. V. Lyulko, G. Randers-Pehrson, D. J. Brenner, Columbia Univ. (United States)

Author Index 


\title{
Conference Committee
}

\author{
Symposium Chairs \\ James G. Fujimoto, Massachusetts Institute of Technology (United \\ States) \\ R. Rox Anderson, Wellman Center for Photomedicine, Massachusetts \\ General Hospital (United States), and Harvard School of Medicine \\ (United States)
}

Program Track Chairs

Ammasi Periasamy, University of Virginia (United States)

Daniel L. Farkas, Cedars-Sinai Medical Center (United States)

Conference Chairs

Daniel L. Farkas, Cedars-Sinai Medical Center (United States)

Dan V. Nicolau, The University of Liverpool (United Kingdom)

Robert C. Leif, Newport Instruments (United States)

Conference Cochairs

James F. Leary, Purdue University (United States)

Ramesh Raghavachari, U.S. Food and Drug Administration (United States)

J. Paul Robinson, Purdue University (United States)

Attila Tárnok, Universität Leipzig (Germany)

Program Committee

Vincenza Andrisano, Università degli Studi di Bologna (Italy)

Christopher H. Contag, Stanford University School of Medicine (United States)

Ewa M. Goldys, Macquarie University (Australia)

Charles P. Lin, Massachusetts General Hospital (United States)

Andreas G. Nowatzyk, Cedars-Sinai Medical Center (United States)

Markus Sauer, Universität Bielefeld (Germany)

Takahisa Taguchi, National Institute of Advanced Industrial Science and Technology (Japan) 


\author{
Session Chairs \\ 1 Cell Imaging \\ Daniel L. Farkas, Cedars-Sinai Medical Center (United States) \\ 2 Tissue Imaging \\ Daniel L. Farkas, Cedars-Sinai Medical Center (United States) \\ 3 Micro: Imaging, Manipulation, Probing \\ Dan V. Nicolau, The University of Liverpool (United Kingdom) \\ $4 \quad$ Biomolecular Imaging \\ Dan V. Nicolau, The University of Liverpool (United Kingdom) \\ 5 Cytomics \\ Robert C. Leif, Newport Instruments (United States) \\ Attila Tárnok, Universität Leipzig (Germany) \\ $6 \quad$ New Imaging Techniques \\ Robert C. Leif, Newport Instruments (United States) \\ Attila Tárnok, Universität Leipzig (Germany)
}

